\title{
CHARAKTERYSTYKA OPADÓW ATMOSFERYCZNYCH W GORZOWIE WIELKOPOLSKIM W LATACH 1951-2016
}

\author{
*KATARZYNA SZYGA-PLUTA, DOMINIKA WOJTKOWIAK \\ Zakład Meteorologii i Klimatologii, Instytut Geografii Fizycznej i Kształtowania Środowiska \\ Przyrodniczego, Wydział Nauk Geograficznych i Geologicznych, \\ Uniwersytet im. Adama Mickiewicza w Poznaniu , ul. B. Krygowskiego 10, 61-680 Poznań \\ *ORCID: 0000-0001-9718-3920
}

\begin{abstract}
The purpose of the work is to characterize the precipitation occurrence and the synoptic conditions of the extreme cases in Gorzów Wielkopolski. In the paper the daily precipitation data from IMGW-PIB for Gorzów Wielkopolski station in years 1951-2016 were used. The average monthly, annual and seasonal sums were calculated and the intensity of precipitation was analyzed. Days without any precipitation were also included. Special attention was paid to extreme precipitation cases and their synoptic conditions. The average precipitation in the research period was $547,1 \mathrm{~mm}$. On average, as much as $80 \%$ during the year were days with very low $(0.1-1.0 \mathrm{~mm})$ and low $(1.1-5.0 \mathrm{~mm})$ precipitation, and $13 \%$ with moderate $(5.1-10.0 \mathrm{~mm})$. Extreme daily precipitation totals in Gorzów Wielkopolski ( $95^{\text {th }}$ percentile) occur mainly in summer and spring. They are associated with the transition of the atmospheric front or with the development of convection over heated land.
\end{abstract}

Keywords: precipitation total, extreme precipitation, Gorzów Wielkopolski

\section{WSTĘP}

Opady atmosferyczne są niezwykle ważnym elementem meteorologicznym warunkującym życie na całym świecie. Zarówno ich nadmiar, jak i niedobór doprowadza do poważnych problemów środowiskowych, powoduje zagrożenie dla życia ludzi, może również przyczynić się do katastrof.

Opracowania dotyczące opadów atmosferycznych w Polsce obejmują przede wszystkim zagadnienia dotyczące ich przestrzennego i czasowego zróżnicowania na obszarze kraju (Boryczka, Stopa-Boryczka 2004; Kirschenstein, Baranowski 2005; Stach 2009; Woś 2010; Czarnecka, Nidzgorska-Lencewicz 2012) lub regionów czy pojedynczych stacji, np. Wielkopolski (Szyga-Pluta 2018), Wrocławia (Kotowski i in. 2010), Koniczynki (Uscka-Kowalkowska, Kejna 2009), Szczecina (Kirchenstein 2007), Poznania (Szyga-Pluta, Grześkowiak 2016) oraz warunków opadowych na stacji agrometeorologicznej w Garlicy Murowanej (Olechnowicz-Bobrowska i in. 2005).

Skrajne warunki pluwiotermiczne w okresie wiosennym analizowały Skowera i Puła (2004), a ekstremalne warunki pluwialne z uwzględnieniem wszystkich pór roku - Skowera i Bokwa (2009). Według Kirchenstein (2007) oraz Mrugały 
(2001) opady charakteryzują się dużą zmiennością zarówno przestrzenną, jak i czasową. Dotyczy to mniejszych obszarów badań, np. jednego miasta - Szczecina, a także całej Polski. Znaczące zróżnicowanie czasowe oraz przestrzenne trendów sezonowych i rocznych sum opadów i intensywności opadów na obszarze Niemiec opisywali m.in.: Moberg i in. (2006), Trömel i Schönwiese (2007), Zolina i in. (2008), Hänsel i in. (2009), Schwarzak i in. (2014), Duan i in. (2016), Łupikasza $\mathrm{i}$ in. (2011). Istnieje wiele publikacji dotyczących opadów atmosferycznych i ich uwarunkowań synoptycznych (Twardosz 2000, 2005; Niedźwiedź i in. 2011), a także odnoszących się do wystąpienia niedoborów i nadmiarów opadów atmosferycznych w Polsce (Kaczorowska 1962; Mrugała 2001), na poszczególnych stacjach (Kossowska-Cezak, Mrugała 1999; Skowera, Bokwa 2009) i regionach (Zawora, Ziernicka-Wojtaszek 2008; Siwek 2010). Uwarunkowaniami ekstremalnych opadów zajmowali się: Cebulak (1992ab), Wibig i Fortuniak (1998), Kaszewski i Siwek (2005) oraz Świątek (2005). Opadom ekstremalnie wysokim poświęcono uwagę również w Atlasie ekstremalnych zjawisk meteorologicznych oraz sytuacji synoptycznych w Polsce (Ustrnul, Czekierda 2009).

Celem pracy była charakterystyka zmienności występowania opadów w Gorzowie Wielkopolskim w latach 1951-2016, obejmująca przebieg wieloletni i roczny sum opadów oraz liczby dni bez opadu i z opadem o określonej wielkości. Opisano także sytuacje synoptyczne występowania opadów ekstremalnych w badanej stacji.

\section{OBSZAR, MATERIAŁ ŹRÓDŁOWY I METODY BADAŃ}

Równina Gorzowska charakteryzuje się przeciętną sumą opadów atmosferycznych, ze średnią roczną równą $550 \mathrm{~mm}$. Najmniej opadów przypada na luty i marzec (śr. $29 \mathrm{~mm}$ ), natomiast najwięcej na miesiące letnie, zwłaszcza na czerwiec (64 mm) i lipiec (73 mm) (Woś 1994). Gorzów Wielkopolski leży w obszarze narażonym na niebezpieczeństwo wystąpienia powodzi (ryc. 1). Wskaźnik zagrożenia powodziowego (WZP), który określa rzeczywisty stopień zagrożenia powodzią na Warcie, jest wysoki i wynosi tam 0,8032 (Ozga-Zielińska i in. 2003).

Dobowe sumy opadów, będące podstawą analizy, pochodzą z bazy danych zgromadzonych przez Instytut Meteorologii i Gospodarki Wodnej - Państwowy Instytut Badawczy (IMGW-PIB). Na podstawie sum dobowych opadów atmosferycznych obliczono średnie sumy miesięczne i roczne. Szczególną uwagę poświęcono występującym w badanym wieloleciu opadom ekstremalnym. Ponadto dokonano analizy intensywności opadów na podstawie klasyfikacji Olechnowicz-Bobrowskiej (1970):
opady bardzo słabe
$0,1-1,0 \mathrm{~mm}$,
opady słabe
$1,1-5,0 \mathrm{~mm}$,
opady umiarkowane
5,1-10,0 mm, 


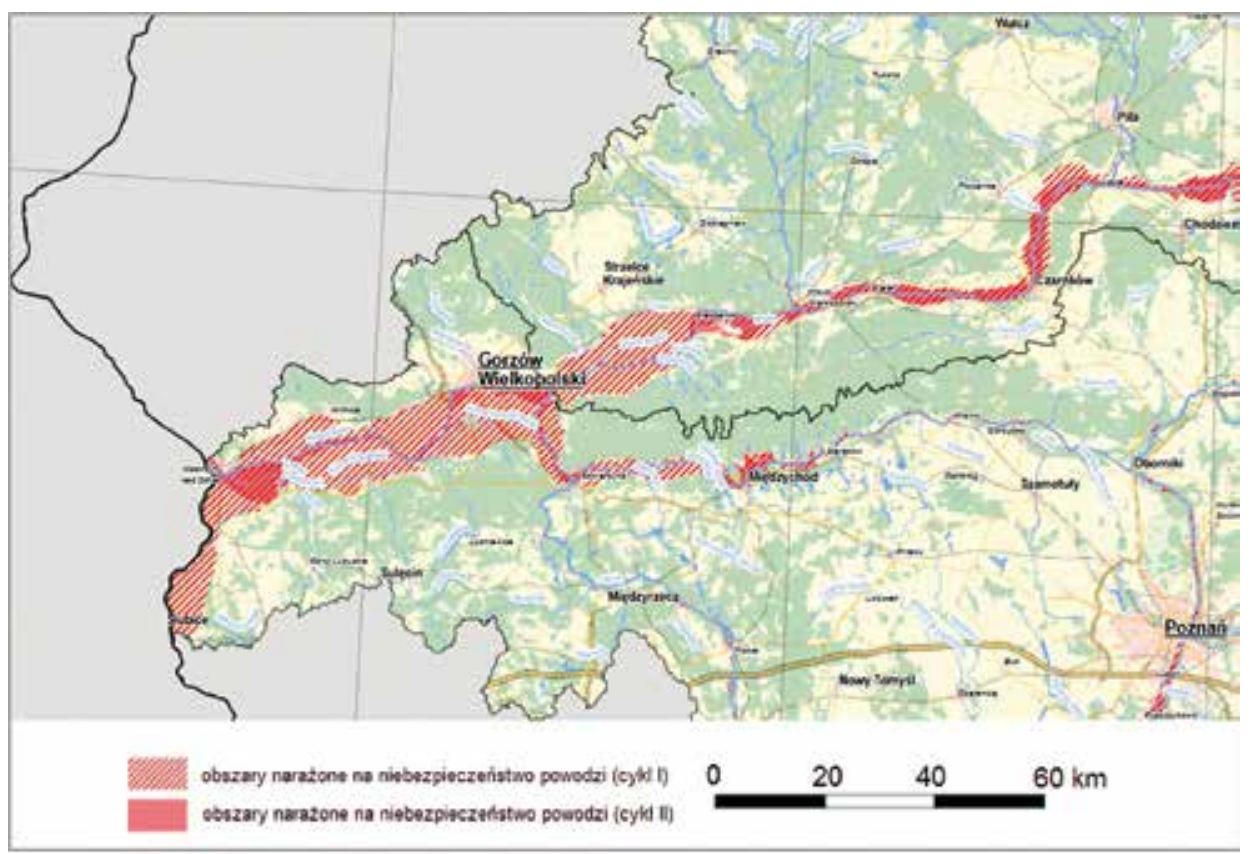

Ryc. 1. Obszary narażone na niebezpieczeństwo powodzi w okolicach Gorzowa Wlkp. Źródło: Opracowanie własne na podstawie: <www.kzgw.gov.pl>

Fig. 1. Areas at risk of flooding in the vicinity of Gorzów Wielkopolski

opady umiarkowanie silne $\quad 10,1-20,0 \mathrm{~mm}$, opady silne 20,1-30,0 mm, opady bardzo silne $\quad \geq 30,1 \mathrm{~mm}$.

$\mathrm{W}$ pracy uwzględniono również sezonowość opadów, z podziałem na sezon ciepły (marzec-sierpień) i chłodny (wrzesień-luty). Dla wybranych dni z opadem ekstremalnym, wyznaczonych na podstawie wartości 95. percentyla, przeanalizowano mapy synoptyczne pochodzące z „Codziennego Biuletynu Meteorologicznego", udostępnione dzięki uprzejmości pracowników oddziału IMGW-PIB w Poznaniu.

\section{WYNIKI}

\section{Przebieg wieloletni opadów atmosferycznych w Gorzowie Wielkopolskim}

W latach 1951-2016 średnia roczna suma opadów atmosferycznych w Gorzowie Wielkopolskim wynosiła $547,1 \mathrm{~mm}$. Jest to wartość charakteryzująca 
opad atmosferyczny na nizinach polskich, które są obszarami o najmniejszych opadach w Polsce. Znacznie większe sumy odnotowuje się na północy kraju, a największe na południu, na obszarach górskich (Woś 1999). Podobnie w latach 1951-1980 średnia roczna suma opadów w Gorzowie Wlkp. wynosiła $556 \mathrm{~mm}$ (Woś 1994). Analogiczne wyniki otrzymała Kirschenstein (2005), która badała okres 1861-1996. W tym czasie w Gorzowie Wlkp. średnia wieloletnia suma opadów wyniosła $546 \mathrm{~mm}$.

Przebieg opadów w analizowanych latach (1951-2016) był bardzo zróżnicowany. Na rycinie 2 widoczne są istotne wahania sum opadów z roku na rok, ale nie stwierdza się tendencji tych zmian. Najbardziej obfitym w opady był rok 1967 , kiedy roczna suma opadów wyniosła $749,3 \mathrm{~mm}$. Zatem była ona wyższa od przeciętnej w rozpatrywanym okresie w Gorzowie o około 37\%. Najmniej opadów odnotowano w roku $1982(335,4 \mathrm{~mm})$. Jest to wynik o $38 \%$ niższy od średniej w Gorzowie Wlkp.

Badane wielolecie charakteryzowało się dużym zróżnicowaniem odchyleń rocznych sum opadów od wartości średniej z okresu 1951-2016 (ryc. 3). Do roku 1954 widoczne są wartości mniejsze od średniej, po czym nastąpił niewielki wzrost $\mathrm{z}$ wartościami powyżej średniej. W roku 1959 opady były niższe od średniej aż o $188 \mathrm{~mm}$. Następnie wystąpił jeden z najdłuższych okresów z wysokimi dodatnimi odchyleniami, $\mathrm{z}$ wartość najwyższą $(202,4 \mathrm{~mm}) \mathrm{w}$ badanym wieloleciu w 1967 r. Kolejne lata były bardzo zróżnicowane. Najdłuższe okresy z ujemnym odchyleniem odnotowywano w następujących latach: 1951-1954, 1982-1986, 1989-1992 i 2013-2016. Największe ujemne odchylenie przypada na rok najbardziej suchy - 1982. Najdłuższe okresy z dodatnim odchyleniem wystąpiły w latach 1964-1968, 1998-2002 oraz 2006-2010.



Ryc. 2. Roczne sumy opadów atmosferycznych w Gorzowie Wlkp. (1951-2016) wraz z linią trendu

Fig. 2. Annual total precipitation in Gorzów Wielkopolski (1951-2016) with the trend line 


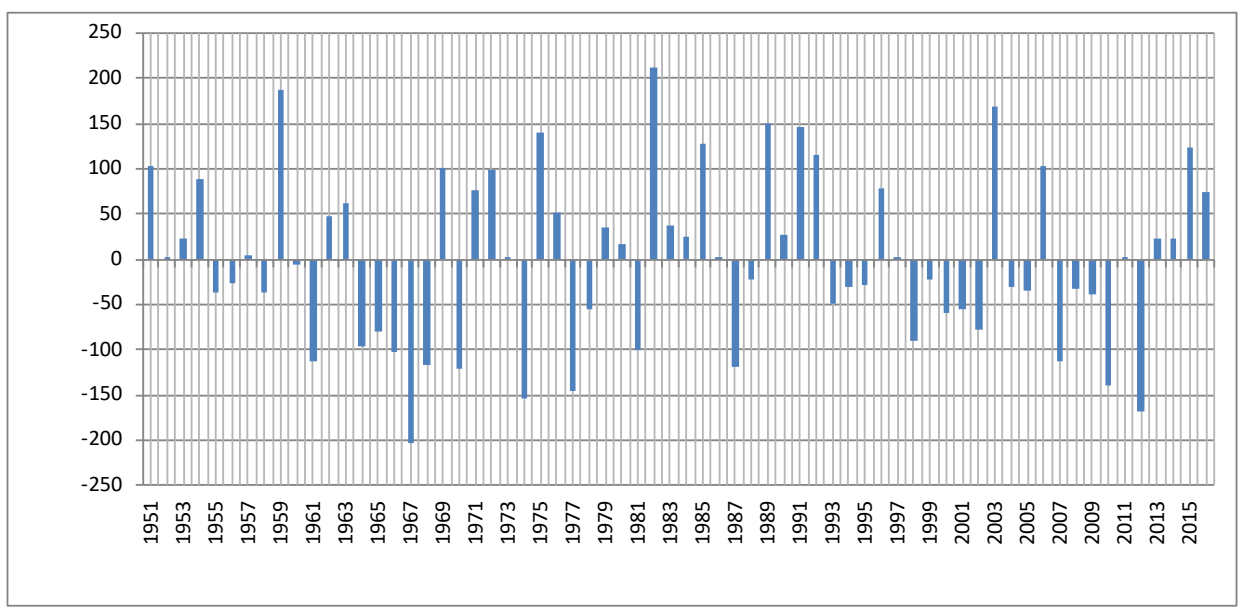

Ryc. 3. Odchylenia rocznych sum opadów atmosferycznych w Gorzowie Wlkp. od wartości średniej w latach 1951-2016

Fig. 3. Deviations of the annual total precipitation in Gorzów Wielkopolski from the average value in the years 1951-2016

\section{Roczny przebieg opadów atmosferycznych}

Opady atmosferyczne w Gorzowie Wlkp. charakteryzowały się wyraźnym przebiegiem rocznym. Najwięcej opadów przypadało na miesiące letnie, zwłaszcza na lipiec (tab. 1). Najmniejsze opady występowały w lutym (31,2 mm). Taki wynik uzyskali także Olechnowicz-Bobrowska i in. (2005). Od tego miesiąca widoczny jest stopniowy wzrost sumy opadów aż do momentu kulminacji w lipcu $(71,3 \mathrm{~mm})$. Następnie odnotowuje się spadek opadów do października $(38,1 \mathrm{~mm})$. Kirschenstein (2007) badając wieloletnie zmiany wielkości opadów w Szczecinie, również stwierdziła najwyższą średnią sumę opadów w lipcu, a najmniejszą w lutym. Podobne wyniki uzyskały Szyga-Pluta i Grześkowiak (2016) w Poznaniu w okresie 1981-2015. W odniesieniu do Poznania w Gorzowie Wlkp. średnia suma opadów w lipcu jest niższa o około $9 \mathrm{~mm}$, a średnia suma w lutym wyższa o około $4 \mathrm{~mm}$. Niemalże we wszystkich miesiącach, z wyjątkiem lipca, w Gorzowie Wlkp. odnotowuje się wyższe średnie sumy miesięczne niż w Poznaniu. Średnie miesięczne sumy opadów w Gorzowie Wlkp. w latach 1951-1980 analizował także Woś (1994). Wyniki uzyskane w niniejszym opracowaniu potwierdzają wcześniejsze rezultaty. Tylko w styczniu, lutym i marcu w wieloleciu 1951-2016 średnia suma opadów jest wyższa, natomiast w pozostałych niższa.

Największe zróżnicowanie opadów atmosferycznych występowało w miesiącach letnich (tab. 1). Współczynnik zmienności niemalże we wszystkich miesiącach, poza grudniem, wyniósł powyżej 50\%. Największa wartość współczynnika 


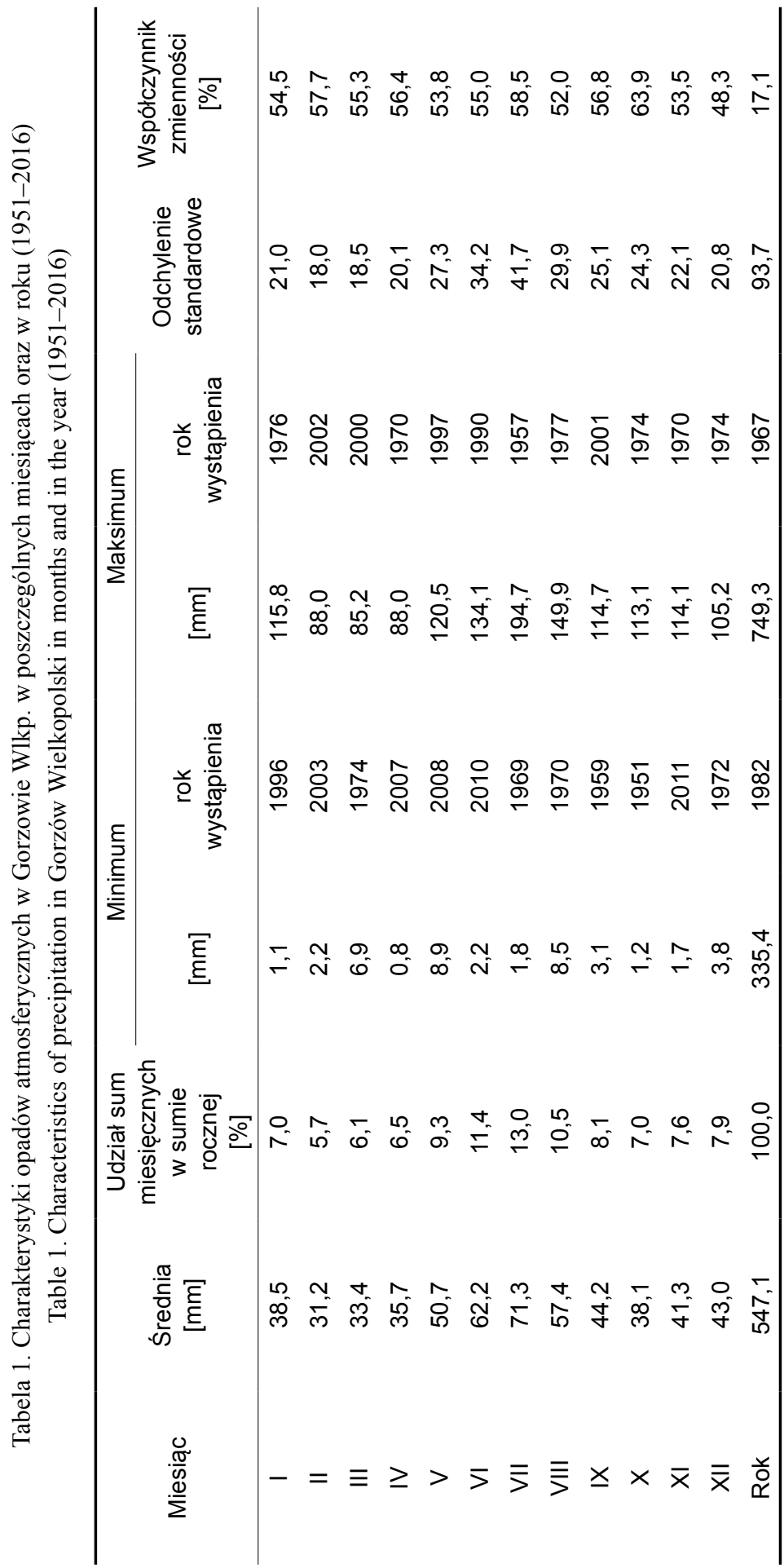


zmienności przypada na październik (63,9\%), natomiast najmniejsza na grudzień $(48,3 \%)$. Wartość odchylenia standardowego w ciągu roku wynosiła $93,7 \mathrm{~mm}$. Najwyższym odchyleniem standardowym charakteryzuje się lipiec $(41,7 \mathrm{~mm})$, natomiast najmniejszym luty $(18,0 \mathrm{~mm})$. Podobne wyniki uzyskały Szyga-Pluta i Grześkowiak (2016) w Poznaniu, gdzie w latach 1981-2015 najniższa wartość odchylenia standardowego przypadała na luty $(14,5 \mathrm{~mm})$, najwyższa na lipiec (51,7 mm). Współczynnik zmienności w roku był wyższy - 20,3\%.

W Gorzowie Wlkp. widoczna jest zdecydowana przewaga opadów półrocza ciepłego (tab. 2). Najwyższe opady występują na tej stacji w lecie, następnie jesienią, wiosną i zimą. Zgodnie z układem pór roku o najbardziej obfitych opadach, czyli LJWZ, stację tę można zaliczyć do typu pomorskiego według podziału Kożuchowskiego i Wibig (1988). Jest on charakterystyczny dla środkowej oraz północno-wschodniej części Polski, a także dla zachodniej części Pojezierza Pomorskiego.

Tabela 2. Średnie sumy opadów atmosferycznych w poszczególnych sezonach i ich udział [\%] w Gorzowie Wlkp. w latach 1951-2016

Table 2. Average total precipitation in particular seasons and its share [\%] in Gorzów Wielkopolski in the years 1951-2016

\begin{tabular}{lcc}
\hline \multicolumn{1}{c}{ Okres } & Średni opad [mm] & Udział [\%] \\
\hline Wiosna & 119,9 & 21,9 \\
Lato & 191,0 & 34,9 \\
Jesień & 123,6 & 22,6 \\
Zima & 112,5 & 20,6 \\
Półrocze ciepłe (III-VIII) & 310,9 & 56,8 \\
Półrocze chłodne (IX-II) & 236,1 & 43,2 \\
\hline
\end{tabular}

\section{Liczba dni bez opadu i z opadem o określonej intensywności}

Analizując wystąpienie dni bez opadu w danym wieloleciu, z roku na rok można zaobserwować dużą zmienność, a jednocześnie brak tendencji zmiany w całym okresie (ryc. 4). Najwięcej dni bez opadu wystąpiło w 1982 r. - 238, najmniej zaś w 1965 r. - to 165 dni. W Gorzowie Wlkp. średnia roczna liczba dni z opadem w latach 1951-2016 wynosiła 168 dni. Natomiast średnia liczba dni w roku bez opadu to 197, czyli przez większą część roku nie występowały opady.

Biorąc pod uwagę natężenie opadu, w Gorzowie Wlkp. najczęściej występowały opady bardzo słabe (tab. 3). Średnia liczba dni z opadem w roku malała wraz ze wzrostem ich intensywności. Udział opadów o określonym natężeniu zmienia się w ciągu roku. W okresie chłodnym częściej pojawiają się opady słabsze, a w ciepłym opady o większym natężeniu. 


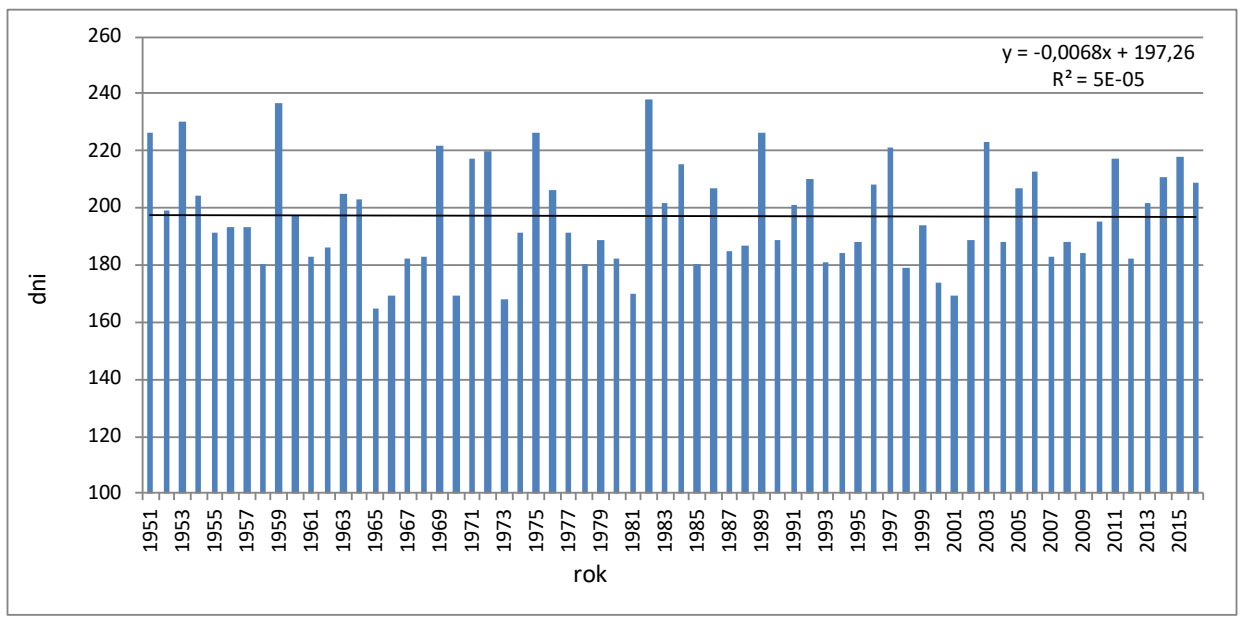

Ryc. 4. Liczba dni bez opadu w Gorzowie Wlkp. w latach 1951-2016 wraz z linią trendu Fig. 4. Number of days without precipitation in Gorzów Wielkopolski in the years 1951-2016 with the trend line

Przeciętnie najwięcej dni z opadem bardzo słabym $(0,1-1,0 \mathrm{~mm})$ występowało w styczniu i grudniu. Najwięcej opadów słabych $(1,1-5,0 \mathrm{~mm})$ również odnotowano $\mathrm{w}$ tych miesiącach, $\mathrm{z}$ niewielką przewagą $\mathrm{w}$ grudniu. Najwięcej opadów umiarkowanych $(5,1-10,0 \mathrm{~mm})$ pojawiało się w lipcu, sierpniu, a także w grudniu. Opady umiarkowanie silne $(10,1-20,0 \mathrm{~mm})$ najczęściej występowały latem (czerwiec-sierpień). Opady silne oraz bardzo silne notowano stosunkowo rzadko i głównie latem (tab. 3). W badanym wieloleciu w Gorzowie Wlkp. wystąpiło łącznie 51 dni z dobowym opadem przekraczającym $30 \mathrm{~mm}$. Tej wielkości opad dobowy występował głównie w lipcu, a także w maju, czerwcu i sierpniu. W marcu i kwietniu oraz od września do listopada odnotowano tylko po jednym takim dniu.

\section{Występowanie opadów ekstremalnych}

Maksymalne sumy dobowe opadów w Gorzowie Wlkp. w latach 1951-2016 wahały się od 19,4 mm w grudniu do 77,5 mm w sierpniu (tab. 4). Zdecydowanie najwyższe wystąpiły od maja do sierpnia. Zimą nie przekroczyły $30 \mathrm{~mm}$. Maksymalne opady zimą odnotowano w ostatnim okresie, tzn. w latach 20072014. Bardzo wysokie sumy dobowe okresu letniego przypadły na lata 70. i 90. XX w.

Opady ekstremalne zostały wyznaczone na podstawie wartości 95. percentyla. Szczególnie wysokie wartości opadów tak wyznaczone to sumy dobowe powyżej $69,9 \mathrm{~mm}$. W całym badanym okresie wystąpiły trzy takie przypadki: 





8.08.1977 r., 20.07.1975 r. i 14.05.1997 r. Najwyższą sumę dobową opadów zanotowano 8.08.1977 r., kiedy spadło 77,4 mm opadu (tab. 4). Na drugim miejscu pod względem największego dobowego opadu znalazł się 20.07.1975 r. $\mathrm{z}$ dobową sumą opadów wynoszącą $75,1 \mathrm{~mm}$. Szczególnym dniem był także 14.05.1997 r., kiedy w ciągu dnia spadło aż 70,8 mm opadu.

Tabela 4. Maksymalne sumy dobowe opadów atmosferycznych w poszczególnych miesiącach w Gorzowie Wlkp. (1951-2016)

Table 4. Maximum daily total precipitation in individual months in Gorzów Wielkopolski (1951-2016)

\begin{tabular}{ccc}
\hline \multirow{2}{*}{ Miesiąc } & \multicolumn{2}{c}{ Maksimum dobowe } \\
\cline { 2 - 3 } & {$[\mathrm{mm}]$} & data \\
\hline I & 29,7 & 18.02 .2007 \\
III & 23,3 & 5.022011 \\
IV & 43,5 & 11.03 .1981 \\
V & 34,7 & 11.04 .1983 \\
VI & 70,8 & 14.05 .1997 \\
VII & 68,7 & 9.06 .1990 \\
VIII & 75,1 & 20.07 .1975 \\
IX & 77,4 & 8.08 .1977 \\
X & 42,3 & 10.09 .1983 \\
XI & 34,1 & 9.10 .1964 \\
XII & 31,3 & 6.11 .1968 \\
& 19,4 & 22.12 .2014 \\
\hline
\end{tabular}

\section{Warunki synoptyczne podczas ekstremalnych opadów dobowych}

Na podstawie map synoptycznych sprawdzono, jakie warunki synoptyczne sprzyjały pojawieniu się wyjątkowo wysokich sum opadów w Gorzowie w badanym wieloleciu (1951-2016).

\section{Dnia 8.08.1977 r. - opady $77,4 \mathrm{~mm}$}

Pogodę w Europie Środkowej kształtował układ niskiego ciśnienia z frontami atmosferycznymi (ryc. 5). Nad Polską przeszedł front chłodny z intensywnymi opadami deszczu, związany z niżem przesuwającym się znad Morza Północnego. Następnie rozwinął się front zokludowany. Nad Skandynawią rozbudował się bardzo rozległy klin wysokiego ciśnienia. Na zachodzie Polski wystąpiło duże zachmurzenie i związane z nim intensywne, przelotne opady 


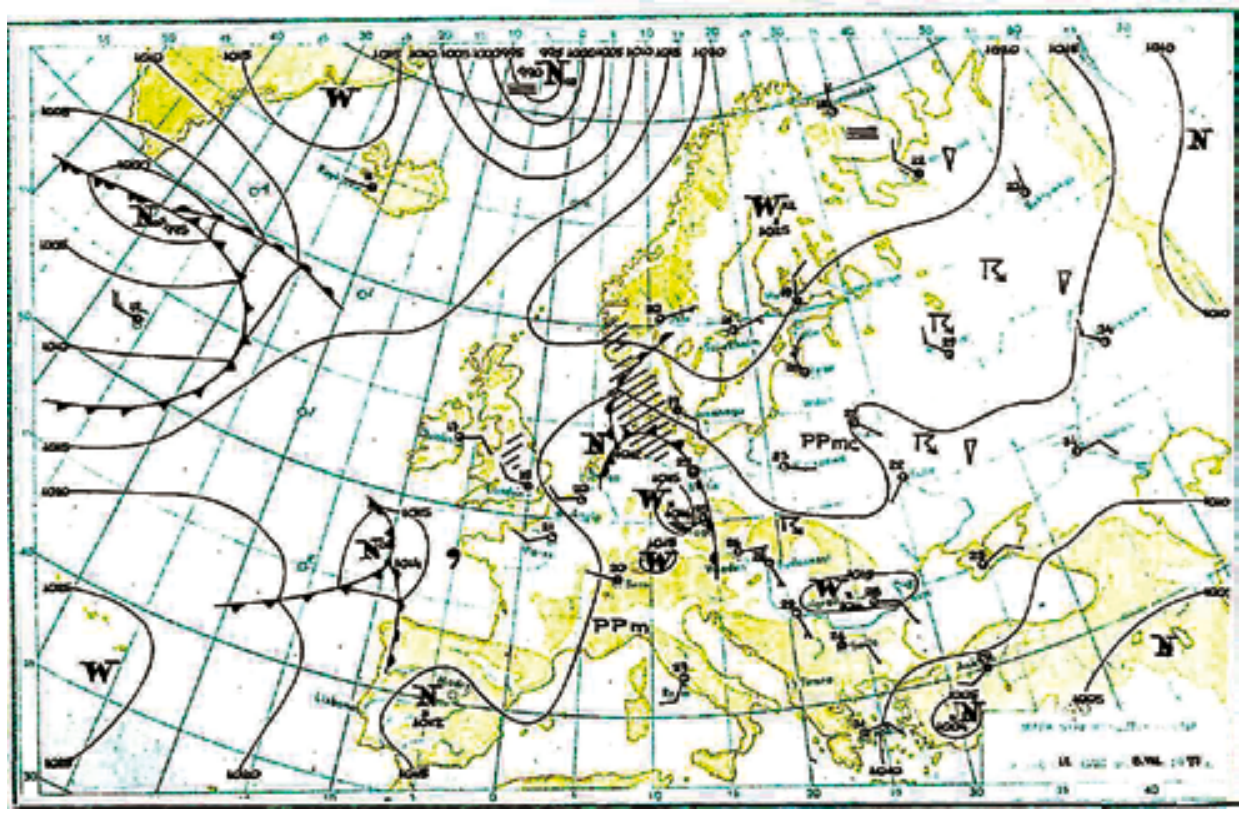

Ryc. 5. Sytuacja synoptyczna w Europie dnia 8 sierpnia 1977 roku o godzinie 12:00 UTC Źródło: Codzienny Biuletyn Meteorologiczny, 1977, IMGW-PIB.

Fig. 5. Synoptic situation in Europe on August 8, 1977 at 12:00 UTC

deszczu i burze. Wiatr wiał ze wschodu, jednak przy zachodniej granicy Polski skręcał w kierunku zachodnim. Według Atlasu ekstremalnych zjawisk meteorologicznych oraz sytuacji synoptycznych w Polsce (Ustrnul, Czekierda 2009) ten wysoki opad w Gorzowie Wlkp. związany był z napływem powietrza z sektora wschodniego.

\section{Dnia 20.07 .1975 r. - opady $75,1 \mathrm{~mm}$}

20.07.1975 r. był dniem pochmurnym, z układem niskiego ciśnienia nad Polską i rozległą strefą opadów (ryc. 6). Nad Skandynawią oraz nad Europą Środkowo-Wschodnią ulokowały się układy niskiego ciśnienia. Wysokie sumy opadów odnotowane tego dnia w Gorzowie Wlkp. były uwarunkowane przejściem ciepłego frontu atmosferycznego rozdzielającego morskie i kontynentalne masy powietrza polarnego PPm i PPk.

\section{Dnia 14.05.1997 r. - opady $70,8 \mathrm{~mm}$}

Bardzo wysokie opady 14.05.1997 r. wiązały się z wyżem zalegającym nad północną Europą. W tym dniu Polska znajdowała się w układzie wysokiego 


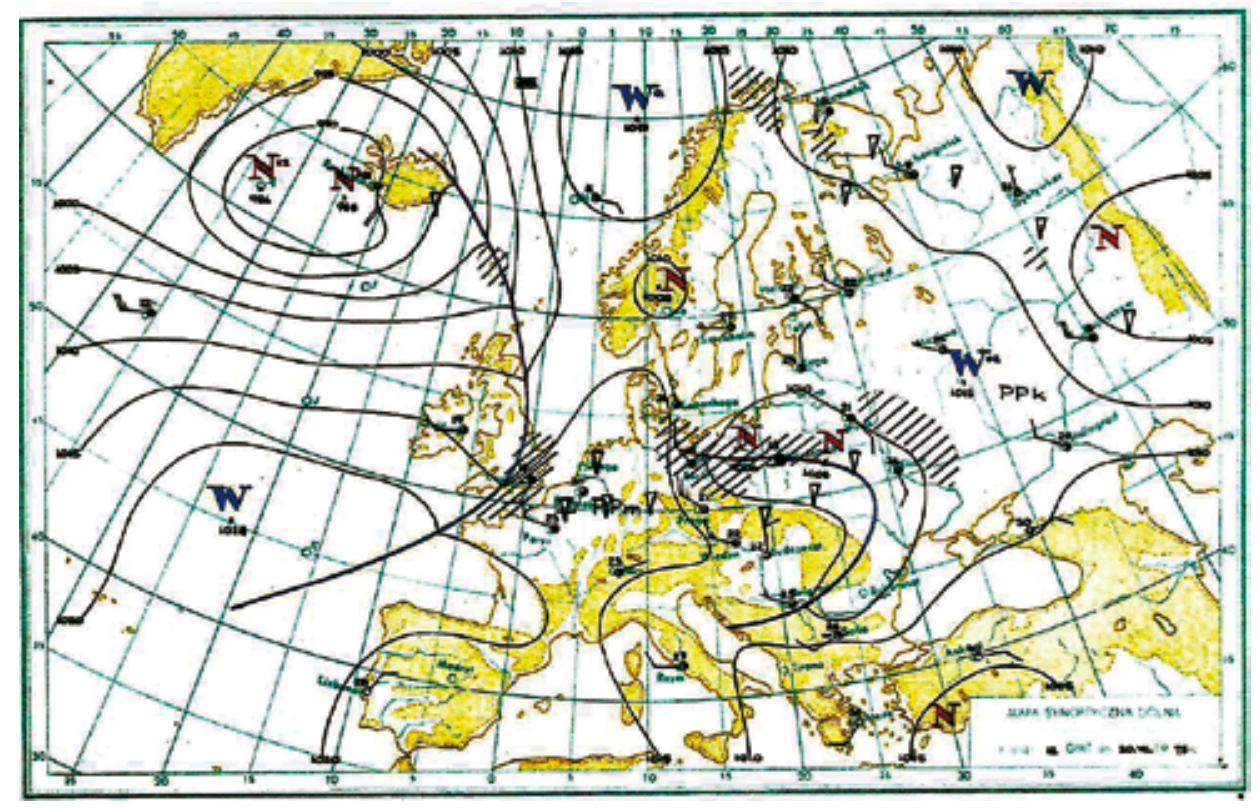

Ryc. 6. Sytuacja synoptyczna w Europie dnia 20 lipca 1975 roku o godzinie 12:00 UTC Źródło: Codzienny Biuletyn Meteorologiczny, 1975, IMGW-PIB.

Fig. 6. Synoptic situation in Europe on July 20, 1975 at 12:00 UTC

ciśnienia z centrum nad Morzem Bałtyckim (ryc. 7). Nad Polskę napływało wilgotne powietrze PPm. Ekstremalna suma dobowa opadów $(70,8 \mathrm{~mm})$ pochodziła $\mathrm{z}$ intensywnych, krótkotrwałych opadów podczas przejścia burzy w Gorzowie Wlkp.

\section{PODSUMOWANIE I DYSKUSJA}

Opady atmosferyczne w Gorzowie Wlkp. charakteryzują się dużą zmiennością czasową. Różnica wysokości opadów w następujących po sobie latach może wynosić nawet $200 \mathrm{~mm}$. Najwyższe opady atmosferyczne wystąpiły w latach 1967, 2012 i 1974, natomiast najniższe w latach 1982, 1959 i 2003. Jednocześnie zaznacza się brak tendencji zmiany w przebiegu wieloletnim opadów. Duan $\mathrm{i}$ in. (2016) stwierdzili wzrost opadów rocznych w 66\% stacji w Niemczech (szczególnie tych w północnej i wschodniej części) oraz znaczące zróżnicowanie czasowe i przestrzenne trendów sezonowych sum opadów w latach 1951-2013.

W Gorzowie Wlkp. najwyższe opady występują w lecie, następnie jesienią, wiosną i zimą, czyli zgodnie z rozkładem LJWZ stację tę można zaliczyć do typu 

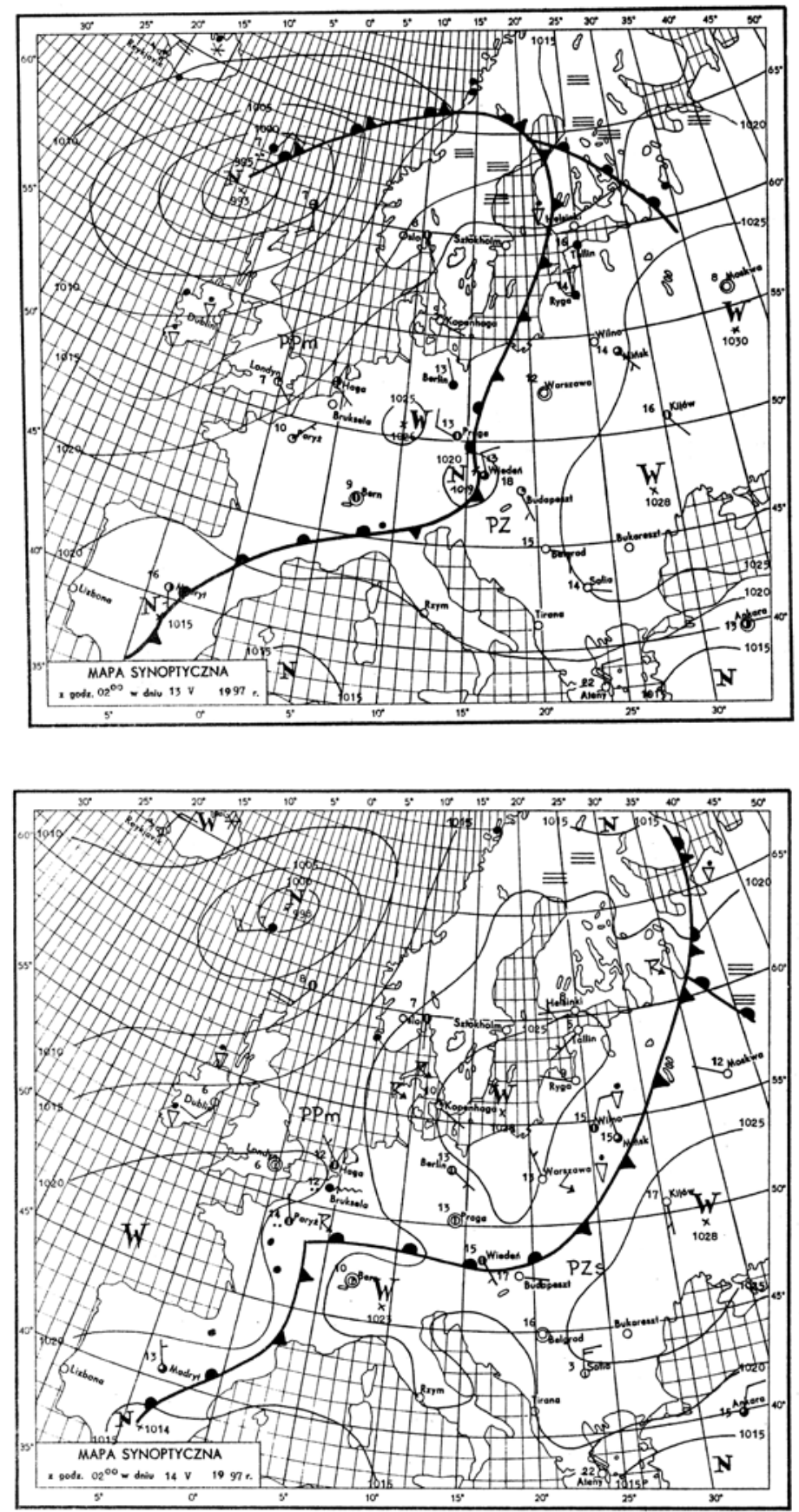

Ryc. 7. Sytuacja synoptyczna w Europie dnia 13 i 14.05.1997 r. o godzinie 02:00 UTC Źródło: Codzienny Biuletyn Meteorologiczny, 1997, IMGW-PIB.

Fig. 7. Synoptic situation in Europe on May 13 and 14, 1997 at 02:00 UTC 
pomorskiego według podziału Kożuchowskiego i Wibig (1988). Podobny wynik dla Gorzowa Wlkp. oraz w Szczecinie, Bydgoszczy i Chojnicach otrzymała Kirschenstein (2005), badając wielolecie 1861-1996. Jest on charakterystyczny dla środkowej oraz północno-wschodniej części Polski, a także dla zachodniej części Pojezierza Pomorskiego. Innym rozkładem odznacza się Poznań, gdzie odnotowuje się opady według natężenia w kolejności LWJZ. Zatem przeważają tam opady w półroczu ciepłym (Szyga-Pluta, Grześkowiak 2016), co według Kożuchowskiego i Wibig (1988) jest typem południowej Polski. W północnej i północno-zachodniej Polsce obserwuje się większy udział opadów jesiennych, natomiast mniejszy wiosennych (Czarnecka, Nidzgorska-Lencewicz 2012). W Gorzowie Wlkp. widoczna jest zdecydowana przewaga opadów półrocza ciepłego. Wynika to głównie z natężenia opadów letnich, a nie częstości występowania (Woś 1994). Słabą tendencję do wzrostu intensywności opadów w lecie przy jednoczesnym zmniejszeniu ich częstości w latach 1901-2000 w Niemczech stwierdzili Moberg i in. (2006). Wyższe sumy letnich opadów atmosferycznych często są związane z rozwojem konwekcji nad rozgrzanym lądem (Kirschenstein, 2007).

Biorąc pod uwagę natężenie opadu, w Gorzowie Wlkp. najczęściej występowały opady bardzo słabe. Średnia liczba dni z opadem w roku malała wraz ze wzrostem ich intensywności. Udział opadów o określonym natężeniu zmienia się w ciągu roku. W okresie chłodnym częściej pojawiają się opady słabsze, a w ciepłym - opady o większym natężeniu. W przebiegu rocznym najmniejszym zróżnicowaniem wyróżnia się przedział sum $5,1-10,0 \mathrm{~mm}$. W Krakowie zaś opady w przedziale sum $1,1-5,0 \mathrm{~mm}$ pojawiają się mniej więcej z jednakową częstością w ciągu roku (Twardosz 2000). Średnio w ciągu roku aż 80\% stanowiły dni z opadem bardzo słabym $(0,1-1,0 \mathrm{~mm})$ i słabym $(1,1-5,0 \mathrm{~mm})$, a $13 \%$ z opadem umiarkowanym $(5,1-10,0 \mathrm{~mm})$. W badanym wieloleciu w Gorzowie Wlkp. wystąpiło łącznie 51 dni z dobowym opadem przekraczającym $30 \mathrm{~mm}$. Pojawiały się one głównie w porze letniej i wiosennej. Podobne wyniki uzyskał Twardosz (2000) dla Krakowa, gdzie opady bardzo słabe i słabe stanowiły $76,8 \%$ dnia z opadem w latach 1874-1995, a opady powyżej $20 \mathrm{~mm}$ zaledwie $3 \%$.

Maksymalne sumy dobowe opadów w Gorzowie Wlkp. w latach 1951-2016 wahały się od 19,4 mm w grudniu do 77,5 mm w sierpniu. Szczególnie wysokie sumy opadów, wyznaczone za pomocą 95. percentyla, to sumy dobowe powyżej $69,9 \mathrm{~mm}$. Co warto zauważyć, maksymalne opady dobowe zimą wystąpiły w latach 2007-2014, a bardzo wysokie sumy dobowe okresu letniego przypadły na lata 70. i 90. XX w. We wschodniej części Niemiec w latach 1901-2000 następował spadek prawdopodobieństwa przekroczenia 95. percentyla w lecie i jesienią, a zimą jego wzrost (Trömel, Schönwiese 2007). Zolina i in. (2008) stwierdzili, że we wschodnich i południowych Niemczech zimą, wiosną i jesienią nastąpił wzrost częstości występowania silnych opadów o 13\% na dekadę, a latem jej spadek o 8\% na dekadę. Wzrost częstości występowania bardzo 
silnych i ekstremalnych opadów zimą jest związany z rzadszym pojawianiem się opadów słabych, wyjaśniają Hänsel i in. (2009). Natomiast latem nastąpiło zmniejszenie ilości opadów o różnym natężeniu. Zgodnie z badaniami Łupikaszy i in. (2011) w środkowo-wschodnich Niemczech dominowały rosnące trendy ekstremalnych opadów, natomiast w południowej Polsce dominowały przeciwne tendencje w okresie zimy. Schwarzak i in. (2014) prognozują, że częstość opadów ekstremalnych (99. percentyl) prawdopodobnie wzrośnie pod koniec XXI w. we wszystkich sezonach - nawet latem, mimo prognozowanego spadku ilości opadów w tym okresie.

W całym badanym okresie w Gorzowie Wlkp. wystąpiły trzy przypadki opadów ekstremalnych wyznaczonych za pomocą 95. percentyla: 8.08.1977 r., 20.07.1975 r. i 14.05.1997 r. Były one związane z przejściem frontu atmosferycznego bądź z rozwojem konwekcji nad rozgrzanym lądem. Twardosz (2005) stwierdził, że największe letnie sumy opadów w Krakowie w latach 1886-2002 wynikały z cyrkulacji cyklonalnej. Adwekcja mas z północy i z północnego-wschodu doprowadzała do szczególnie obfitych opadów (w Krakowie nawet powyżej $80 \mathrm{~mm}$ ). Taka cyrkulacja często prowadzi do powodzi. Ustrnul i Czekierda (2009) stwierdzili, że niezależnie od rozpatrywanego kalendarza typów cyrkulacji zdecydowana większość tych ekstremalnie dużych sum opadów wystąpiła w sytuacjach cyklonalnych z napływem powietrza z sektora północnego. Potwierdzają to również wyniki uzyskane przez Twardosza (2000). Opady ekstremalne (powyżej $100 \mathrm{~mm}$ ) na Lubelszczyźnie według Siwka (2010) były głównie spowodowane wystąpieniem w Polsce układów niżowych, także bruzd niskiego ciśnienia, często blokowanych przez wyż. Inną przyczyną było mieszanie się ciepłych mas powietrza (PZ) z chłodnymi (PA bądź PP), w wyniku czego wystąpiły burze.

Duża zmienność czasowa i przestrzenna opadów oraz zróżnicowanie tendencji ich zmian na obszarze Europy Środkowej skłania do dalszej analizy przebiegu opadów zarówno w Gorzowie Wlkp., jak i na większym obszarze.

\section{BIBLIOGRAFIA}

Boryczka J., Stopa-Boryczka M., 2004: Cykliczne wahania temperatury i opadów w Polsce w XX i XXI wieku. Act. Agroph., 3 (1), 21-33.

Cebulak E., 1992a: Maksymalne opady dobowe w dorzeczu górnej Wisty. Zesz. Nauk. UJ, Pr. Geogr., 90, 79-96.

Cebulak E., 1992b: Wplyw sytuacji synoptycznej na maksymalne opady dobowe w dorzeczu górnej Wisty. Fol. Geograph., Ser. Fol. Phys., 23, 81-95.

Codzienny Biuletyn Meteorologiczny, 1975, 1977, 1997: IMGW, Warszawa.

Czarnecka M., Nidzgorska-Lencewicz J., 2012: Wieloletnia zmienność opadów sezonowych $w$ Polsce. Woda-Środowisko-Obszary Wiejskie, 12, 2(38), 45-60.

Duan Z., Chen Q., Chen C., Liu J.Z., Gao H.K., Song X.F., Wei M., 2019: Spatiotemporal analysis of nonlinear trends in precipitation over Germany during 1051-2013 from multiply observation-based gridded products. Internat. Journ. of Clim., 39(4), 2120-2135. 
Hänsel S., Petzold S., Mattchullat J., 2009: Precipitation trend analysis for Central Eastern Germany, [in:] K. Střelcová, C. Matyas, A. Kleidon, M. Lapin, F. Matejka, M. Blaženec, J. Škvarenina, J. Holécy (eds), Bioclimatology and natural hazards. Springer, Netherlands, 29-38.

Kaczorowska Z., 1962: Opady w Polsce w przekroju wieloletnim - tendencje, okresowość oraz prawdopodobieństwo występowania niedoboru i nadmiaru opadów. Pr. Geogr., 33.

Kaszewski B., Siwek K., 2005: Dobowe sumy opadu atmosferycznego $\geq 50 \mathrm{~mm} w$ dorzeczu Wieprza i ich uwarunkowania cyrkulacyjne (1951-2000), [w:] E. Bogdanowicz, U. Kossowska-Cezak, J. Szkutnicki (red.), Ekstremalne zjawiska hydrologiczne i meteorologiczne. PTGeofiz. - IMGW, Warszawa, 122-130.

Kirschenstein M., 2005: Wieloletnie zmiany sum opadów atmosferycznych na wybranych stacjach pótnocno-zachodniej Polski. Słupskie Pr. Geogr., 2, 199-214.

Kirschenstein M., 2007: Wieloletnie zmiany sum opadów w Szczecinie, [w:] K. Piotrowicz, $\mathrm{R}$. Twardosz (red.), Wahania klimatu w różnych skalach przestrzennych $i$ czasowych. Inst. Geogr. i Gosp. Przestrz. UJ, Kraków, 375-382.

Kirschenstein M., Baranowski D., 2005: Sumy opadów atmosferycznych $w$ Polsce w latach 19511995. Bad. Fizjograf. nad Pol. Zach. Ser. A - Geogr. Fiz., 56, 55-72.

Kossowska-Cezak U., Mrugała S., 1999: Opady atmosferyczne o anomalnej wysokości (na przykladzie Warszawy i Lublina). Przegl. Geofiz., 44(1-2), 39-51.

Kotowski A., Dancewicz A., Kaźmierczak B., 2010: Czasowo-przestrzenne zróżnicowanie opadów atmosferycznych we Wrocławiu. Ochrona Środowiska, 32(4), 37-46.

Kożuchowski K., Wibig J., 1988: Kontynentalizm pluwialny w Polsce: zróżnicowanie geograficzne i zmiany wieloletnie. Act. Geograph. Lodz., 55, 41-56.

Łupikasza E.B., Hänsel S., Matschullat J., 2011: Regional and seasonal variability of extreme precipitation trends in southern Poland and central-eastern Germany 1951-2006. Internat. Journ. of Clim., 31, 2249-2271.

Moberg A., Jones P.D., Lister D., Walther A., Brunet M., Jacobeit J. et al., 2006: Indices for daily temperature and precipitation extremes in Europe analyzed for the period 1901-2000. Journ. of Geoph. Res., 11, D22106.

Mrugała S., 2001: Opady atmosferyczne o normalnej i anomalnej wysokości na obszarze Polski (1951-1990). Wyd. UMCS, Lublin.

Niedźwiedź T., Twardosz R., Łupikasza E., 2011: Zmienność i uwarunkowania cyrkulacyjne występowania postaci i typów opadów atmosferycznych na przykładzie Krakowa. Wyd. UJ, Kraków.

Olechnowicz-Bobrowska B., 1970: Częstość dni z opadem w Polsce. Pr. Geogr. nr 86, IG PAN, PWN, Warszawa.

Olechnowicz-Bobrowska B., Skowera B., Wojkowski J., Ziernicka-Wojtaszek A., 2005: Warunki opadowe na stacji agrometeorologicznej w Garlicy Murowanej. Act. Agroph., 6(2), 455-463.

Ozga-Zielińska M., Kupczyk E., Ozga-Zieliński B., Suligowski R., Niedbała J., Brzeziński J., 2003: Powodziogenność rzek pod katem bezpieczeństwa budowli hydrotechnicznych i zagrożenia powodziowego. IMGW, Mat. Badawcze, Ser. Hydrol. i Ocean., 29, 89-90.

Schwarzak S., Hänsel S., Matschullat J., 2015: Projected changes in extreme precipitation characteristics for Central Eastern Germany (21st century, model-based analysis). Internat. Journ. of Clim., 35, 2724-2734.

Siwek K., 2010: Występowanie na Lubelszczyźnie dobowych sum opadu atmosferycznego $\geq 100$ mm i ich uwarunkowania cyrkulacyjne (1951-2000). Ann. UMCS, Sec. B, 65(2), 117-125.

Skowera B., Puła J., 2004: Skrajne warunki pluwiotermiczne $w$ okresie wiosennym na obszarze Polski w latach 1971-2000. Act. Agroph., 3(1), 171-177.

Skowera B., Bokwa A., 2009: Wystepowanie ekstremalnych warunków pluwialnych w Krakowie i okolicy w latach 1971-2005. Act. Agroph., 13(2), 299-310.

Stach A., 2009: Analiza struktury przestrzennej i czasoprzestrzennej maksymalnych opadów dobowych $w$ Polsce w latach 1956-1980. Ser. Geogr. nr 58, Wyd. Nauk. UAM, Poznań. 
Szyga-Pluta K., 2018: Zmienność czasowa i przestrzenna opadów atmosferycznych w Wielkopolsce w latach 1981-2014. Przegl. Geogr., 90, 3, 495-516.

Szyga-Pluta K., Grześkowiak K., 2016: Warunki pluwialne w Poznaniu w latach 1981-2015. Bad. Fizjograf., R VII - Ser. A - Geogr. Fiz., A67, 239-256.

Świątek M., 2005: Synoptyczne uwarunkowania ekstremalnie wysokich opadów atmosferycznych na polskim wybrzeżu Battyku. Czas. Geog., 76(1-2), 91-103.

Trömel S., Schönwiese C.D., 2007: Probability change of extreme precipitation observed from 1901 to 2000 in Germany. Theoretical and Appl. Clim., 87, 29-39.

Twardosz R., 2000: Wieloletnia zmienność sum dobowych opadów w Krakowie w powiazaniu z sytuacjami synoptycznym. Pr. Geogr., 105, 19-71.

Twardosz R., 2005: Dobowy przebieg opadów atmosferycznych w ujęciu synoptycznym i probabilistycznym na przykladzie Krakowa (1886-2002). IGiGP UJ, Kraków.

Uscka-Kowalkowska J., Kejna M., 2009: Zmienność warunków termiczno-opadowych w Koniczynce (Pojezierze Chetmińskie) w okresie 1994-2007. Act. Agroph., 14(1), 203-219.

Ustrnul Z., Czekierda D., 2009: Atlas ekstremalnych zjawisk meteorologicznych oraz sytuacji synoptycznych $w$ Polsce. IMGW, Warszawa.

Wibig J., Fortuniak K., 1998: The extreme precipitation conditions in Lódź in the period 19311995. Act. Univ. Lodz., Fol. Geograph. Phys., 3, 241-249.

Woś A., 1994: Klimat Niziny Wielkopolskiej. Wyd. Nauk. UAM, Poznań.

Woś A., 1999: Klimat Polski. Wyd. Nauk. PWN, Warszawa.

Woś A., 2010: Klimat Polski w drugiej połowie XX wieku. Wyd. Nauk. UAM, Poznań.

Zawora T., Ziernicka-Wojtaszek A., 2008: Ekstremalne wartości niedoborów i nadmiarów opadów atmosferycznych $w$ aspekcie wspótczesnych zmian klimatu na przykładzie województwa podkarpackiego. Infrastruktura i Ekologia Terenów Wiejskich, 5, 23-29.

Zolina O., Simmer C., Kapala A., Bachner S., Gulev S., Maechel H., 2008: Seasonally dependent changes of precipitation extremes over Germany since 1950 from a very dense observational network. Journ. of Geophys. Res., 113, D06110. 